\title{
Multivariate Statistical Analyses of Fluoride and Other Physicochemical Parameters in Groundwater Samples of Two Megacities in Asia: Lahore and Sialkot
}

\author{
Saadia Rashid Tariq \\ Department of Chemistry, Lahore College for Women University, Lahore 45600, Pakistan \\ Correspondence should be addressed to Saadia Rashid Tariq; saadiartariq@yahoo.com
}

Received 31 May 2013; Accepted 22 October 2013; Published 21 January 2014

Academic Editor: Aicheng Chen

Copyright (c) 2014 Saadia Rashid Tariq. This is an open access article distributed under the Creative Commons Attribution License, which permits unrestricted use, distribution, and reproduction in any medium, provided the original work is properly cited.

\begin{abstract}
The present study was carried out to evaluate the current status of contaminants and their sources in groundwater samples collected from Lahore and Sialkot. A total of 93 samples were collected from different localities of Lahore and Sialkot and analyzed for the determination of various physicochemical parameters. The results of the study revealed that mean fluoride and chloride contents of water samples from Lahore were higher than the values recommended by Pak-EPA and WHO whereas the mean nitrate and sulphate levels of these samples were well within the limits. The order observed for these physicochemical parameters from Lahore was $\mathrm{Cl}^{-}>$alkalinity $>\mathrm{SO}_{4}{ }^{-2}>\mathrm{NO}_{3}{ }^{-}>\mathrm{F}^{-}$. All the observed physicochemical parameters for water samples from Sialkot were found to be greater than those of Lahore, due to a more intensive industrial activity in Sialkot. The correlation study revealed the strongest correlation among conductance and alkalinity in samples from both cities. Fluoride and sulphate were found to be positively correlated in samples from Lahore and negatively correlated in samples from Sialkot. Multivariate analysis in terms of principle component analysis and cluster analysis furnished information about the sources of various parameters in groundwater samples.
\end{abstract}

\section{Introduction}

The dynamic balance in the aquatic ecosystem is upset by human activities thereby resulting in its pollution which is manifested dramatically as fish kill, offensive odor, color, and taste, and unchecked aquatic weeds. Fresh, clean water has thus become a scarce commodity. The quality of groundwater depends on various chemical constituents and their concentrations, which are mostly derived from the geological data of the particular region but industrial and municipal wastes also contribute significantly towards it. In fact, high rate of exploration, inappropriate dumping of solid and liquid wastes, and lack of strict enforcement of law have caused the deterioration of groundwater quality [1-6].

In Pakistan, the major sources of drinking water are groundwater and surface water from rivers, lakes, and reservoirs. The indiscriminate disposal of agricultural, industrial, and domestic wastewater into these natural water bodies has caused their serious contamination that has been shown to be associated with deterioration of human health [7-11]. In Lahore and Sialkot, the only source of drinking water available to the public at large is only groundwater, and that too has been contaminated by various anthropogenic activities.

Among the physico-chemical parameters, fluoride is one of the important chemical parameters whose monitoring is of great concern because its compounds are nonbiodegradable and are accumulative. Naturally, fluoride is present virtually in all water sources but does not usually exceed $10 \mathrm{mg} / \mathrm{L}$ [12]. Mostly, industrial waste discharges are responsible for this high fluoride contamination of water resources [13]. The other sources of fluoride include foods and beverages produced in areas with fluoridated water, dentifrices, fluoride containing mouth rinses, dental treatment products, and dietary supplements [14]. The public at large may also be exposed to fluoride from some pesticide residues and pharmaceuticals [15]. 
Groundwater of many areas of the world has been found to be affected by enhanced fluoride levels [16-21]. No matter how little is being added to drinking water, fluoride will accumulate in the bones, teeth, environment, and food chain. Enhanced fluoride levels in the body may result in collagen breakdown, eczema, tissue damage, skin wrinkling, genetic damage, and immune suppression. High fluoride levels change the enzymes thereby leading to the damage of digestive system, respiratory system, blood circulation, kidney function, liver function, brain function, and thyroid function. The major health problems associated with fluoride are dental fluorosis [22]. In certain areas in Punjab the excess fluoride concentrations have also been linked with bone deformations [23]. Thus fluoride determination is also necessary for assessing the need of a specific water treatment and to determine the efficacy of a particular treatment plan [24].

In addition to fluoride, the determination of other physico-chemical parameters such as $\mathrm{pH}$, electrical conductivity, chloride, and alkalinity has established role in evaluating the quality of drinking water. That is why these parameters have also been duly focused on [7, 25-27].

On overall, the quality of drinking water may cast hazardous effects on the health of human beings and this quality is monitored in terms of various parameters like $\mathrm{pH}$, conductivity, alkalinity, and presence of other anions like $\mathrm{F}^{-}$, $\mathrm{Cl}^{-}$, and $\mathrm{NO}_{3}{ }^{-}$. All these parameters must be within safe limits set by health departments; otherwise their presence at enhanced levels will be quite harmful to humans. The objective of present study was therefore to determine the quality of drinking water in terms of these physico-chemical parameters from various residential localities of two big cities of Pakistan, that is, Lahore and Sialkot, that have a long standing tradition of extensive industrial activity. By determining water quality and the effect of different water purification systems on the fluoride content of drinking water, the efficacy of these water purification systems in reducing the fluoride and other anion content can be compared and many diseases may be avoided which are caused by imbalance of these ions in our drinking water.

\section{Experimental Methodology}

The present study was designed to evaluate the contents of fluoride and other anions in the groundwater samples of various localities of Lahore and Sialkot, Pakistan.

2.1. Sampling. For the present investigation $500 \mathrm{~mL}$ of groundwater samples was collected from different localities of Lahore and Sialkot in screw capped high density polyethylene bottles in accordance with prescribed sampling procedure during the months of April and May 2011 [28, 29]. Before the collection of samples, the tap water was allowed to flow continuously for three to four minutes to avoid any retained water in the pipes. Moreover, the sample bottles were rinsed twice with the sample water to avoid any impurity from exogenous source. The sample bottles were labeled properly and immediately transferred to laboratory where they were stored at $4^{\circ} \mathrm{C}$ prior to analysis to avoid any decomposition of sample.

Some of the physico-chemical parameters like $\mathrm{pH}$ and electrical conductivity (EC) were monitored in situ. All the samples were treated as such for the determination of various physico-chemical parameters; that is, no preservatives or stabilizers were added. All the glassware used during the study was of high quality, acid resistant borosilicate glass. For delivering less than one $\mathrm{mL}$ volume of samples or solutions, pipettes of capacity $1.0 \mathrm{~mL}$ were used. The reagents used for the quantification had complete control over their purity and quality, and thus they were having a certified purity of $99.99 \%$.

\subsection{Description of Sampling Sites}

2.2.1. Lahore. Lahore is the second largest city in Pakistan which lies between $31^{\circ} 34^{\prime}$ North latitude and $74^{\circ} 22^{\prime}$ East longitude at an altitude of $214 \mathrm{~m}$. The city is bound by Sheikhupura district in the west and by Wagah on the east, while on south it is surrounded by the Kasur district. On the northern side it is watered by the Ravi River. It encompasses an area of about 404 square kilometers with a semiarid climate. The rainy season is the most pleasant season of the year with an average annual rain fall of $489 \mathrm{~mm}$. The average depth of water table here is 100-150 feet and the soil texture is loamy clay. A number of industrial units are operative in the city, that is, pharmaceuticals, leather, textiles, metallurgy, and polymer synthesis. Sampling plan was designed so as to ensure the sampling from the entire city.

2.2.2. Sialkot. Lying between $32.30^{\circ}$ North latitude and $7431^{\circ}$ East longitude at an altitude of $256 \mathrm{~m}$ above sea level, Sialkot is bounded on the north by Jammu, on the north-west by Gujrat, on the west by Gujranwala, and on the south by Narowal. The Chenab River flows to the north of Sialkot. There are three small seasonal streams flowing through the city, Aik, Bher, and Palkhu. Sialkot district is spread over an area of 3,016 square $\mathrm{km}$. May and June are the hottest months. Average annual rain fall here is $1000 \mathrm{~mm}$. The land is, generally, plain and fertile, that is why 15,000 acres of land is under forest. The depth of water table here is 100-200 feet. Most of the rain falls during the Monsoon season in summer which often results in flooding. The city is well known for export of sports goods, world class high quality leather and textiles.

2.3. Determination of Physicochemical Parameters. Various physico-chemical parameters of water, that is, $\mathrm{pH}$, electrical conductivity, fluoride, chloride, sulphate, nitrate, and TSS, were determined in accordance with standard procedures as outlined below.

The $\mathrm{pH}$ and electrical conductivities of all water samples were measured by using a portable, dual powered, precalibrated WTW, inolab-720 pH meter and conductivity meter, respectively. After each measurement, their electrodes were washed with distilled water and cleaned with a piece of tissue paper. Before the measurement the $\mathrm{pH}$ meter was calibrated by using the buffers of $\mathrm{pH} 4,7$, and 10 . The conductivity meter 
was calibrated by using standard $\mathrm{KCl}$ solution with a reported conductivity of $1413 \mu \mathrm{S} / \mathrm{cm}$ at $25^{\circ} \mathrm{C}$.

Alkalinity of the water samples was determined by titrating a measured volume of water sample with standard $\mathrm{H}_{2} \mathrm{SO}_{4}$. In cases where the $\mathrm{pH}$ of the sample was greater than 8.3, a two-stage titration process yielding phenolphthalein alkalinity and total alkalinity was carried out in accordance with the procedure. a $25 \mathrm{~mL}$ portion of water sample was measured and electrometrically monitored by using a $\mathrm{pH}$ meter. Subsequently, $0.05 \mathrm{M} \mathrm{H}_{2} \mathrm{SO}_{4}$ solution was added with a burette dropwise and the volume of acid required to reach $\mathrm{pH} 8.3$ (phenolphthalein alkalinity) and $\mathrm{pH} 4.5$ (total alkalinity) was recorded [30]. The chloride content of the water samples was determined by using gravimetric; method whereby $\mathrm{AgNO}_{3}$ was allowed to react with chloride anions in the sample solution, and $\mathrm{Cl}^{-}$was precipitated as $\mathrm{AgCl}$ [31].

Spectrophotometric method was used for the determination of sulphate where the sulphate ions present in water samples reacted with barium chloride. For this purpose $10.0 \mathrm{~mL}$ of sample was stirred for five minutes with $\mathrm{NaCl}$ $\mathrm{HCl}$ and glycerol-alcohol solutions, along with approximately $0.03 \mathrm{~g}$ of barium chloride. Immediately, after stirring, the solution was poured into a quartz cell with an optical path of $1 \mathrm{~cm}$ and the absorbance was measured at $420 \mathrm{~nm}$ on a UV spectrophotometer. A series of calibration standards between concentration range of 0.5 and $5 \mathrm{mg} \mathrm{SO}_{4}{ }^{-2} / \mathrm{L}$ were prepared and used for drawing calibration curve. Their absorbance was measured at $420 \mathrm{~nm}$ in the same way as samples [30].

Nitrate present in the groundwater samples was determined by using the sodium salicylic acid method. Here a $10.0 \mathrm{~mL}$ portion of water samples was evaporated with $1.0 \mathrm{~mL}$ of sodium salicylate and cooled to room temperature. Subsequently $1.0 \mathrm{~mL}$ concentrated $\mathrm{H}_{2} \mathrm{SO}_{4}$ was added to dehumidify the entire residue and allowed to stand for 10 minutes. It was then quantitatively transferred to a $50 \mathrm{~mL}$ volumetric flask; $7 \mathrm{~mL} \mathrm{NaOH}$ was added and the volume was adjusted to $50 \mathrm{~mL}$ with distilled water. After 10 minutes, the absorbance was measured at $410 \mathrm{~nm}$ against the blank prepared in the same way. Calibration curve was constructed by using the standard $\mathrm{KNO}_{3}$ solutions in the concentration range of 2$20 \mathrm{mg} / \mathrm{L}$ [32].

Fluoride, present in drinking water, was also determined by spectrophotometric method. For this purpose, a $15.0 \mathrm{~mL}$ portion of drinking water samples was added to $1.0 \mathrm{~mL}$ of $8 \mathrm{~N} \mathrm{H}_{2} \mathrm{SO}_{4}, 4 \mathrm{~mL}$ of $0.0045 \mathrm{M}$ ammonium molybdate, $3 \mathrm{~mL}$ of $0.1816 \mathrm{M}$ hydroquinone, and $4.5 \mathrm{~mL}$ of $0.065 \mathrm{M}$ disodium hydrogen phosphate. A blue coloration was thus developed. The solutions were then left at room temperature for about 30 minutes. Subsequently, $1.0 \mathrm{~mL}$ portion of the solution was taken and diluted up to $10 \mathrm{~mL}$ with corresponding water sample and the absorbance was measured at $715 \mathrm{~nm}$. Calibration curves were then drawn by using the standard fluoride solutions of concentrations of $0.5-7.0 \mathrm{mg} / \mathrm{L}$ and the concentration of fluoride in water samples was determined [33].

2.4. Statistical Data Treatment. The data obtained from physico-chemical parameters, in the groundwater samples, were cast into tables and figures and was also processed for the evaluation of various statistical parameters, like mean, median, mode, standard deviation, and so forth, that are used to measure the distribution and central tendency of the measured data set. Box diagram furnished a clear depiction of the data distribution. Correlation coefficient matrix was determined to know about the interrelationship among the various measured parameters. Multivariate statistical analysis was also carried out in terms of factor analysis and cluster analysis to trace the sources of various parameters in the water samples.

\section{Results and Discussion}

The monitoring of quality of groundwater is important to maintain the human health. The water samples were collected from different localities of the two megacities of Asia, that is, Lahore and Sialkot. On overall basis, fifty-three samples were collected from different locations of Lahore and forty samples were collected from Sialkot (Figure 1) and analyzed for the determination of fluoride and various other physicochemical parameters.

\subsection{Distribution of Physicochemical Parameters among the} Groundwater Samples. The distribution of various physicochemical parameters among various groundwater samples of Lahore and Sialkot is presented in Figure 2. The figure depicted that $\mathrm{pH}$ of most of the groundwater samples from Lahore was slightly alkaline and well within the limits set by Pak-EPA and WHO, while only few samples exhibited an acidic $\mathrm{pH}$. A similar situation was observed in case of samples from Sialkot. Here minimum $\mathrm{pH}$ value recorded was 6.73 , while the highest one was 8.28 . Only two of the samples, that is, from Sambrial and Daska, were observed to exhibit the $\mathrm{pH}$ below the limits set by PAK-EPA. It has been reported that low water $\mathrm{pH}$ values may lead to the corrosion problems in water carrying systems while $\mathrm{pH}$ values higher than recommended ones may hamper the water disinfection through the difficulties in chlorination [34]. Thus the maintenance of appropriate water $\mathrm{pH}$ is quite essential.

The permissible limits for electrical conductivity of groundwater samples set by WHO are $600 \mu \mathrm{S} / \mathrm{cm}$. For the samples collected from Lahore, the highest conductivity values observed were $1353 \mu \mathrm{S} / \mathrm{cm}$, while the conductivity values of the samples from Sialkot ranged from 253 to $1217 \mu \mathrm{S} / \mathrm{cm}$. Only three of the groundwater samples from Sialkot exhibited much elevated conductivity values. Although the EC of groundwater samples from Lahore and Sialkot was found to be greater than permissible limits, it was not greater than $3000 \mu \mathrm{S} / \mathrm{cm}$ - the highest limit of EC for groundwater samples beyond which the germination of almost all seeds would be affected and thus high reduction in crop yields would result [35].

The desirable alkalinity limit for groundwater is $200 \mathrm{mg} / \mathrm{L}$ whereas the permissible limit has been set at $600 \mathrm{mg} / \mathrm{L}$ by WHO. The alkalinity of groundwater samples from Lahore ranged between 100 and $400 \mathrm{mg} / \mathrm{L}$ while slightly higher 


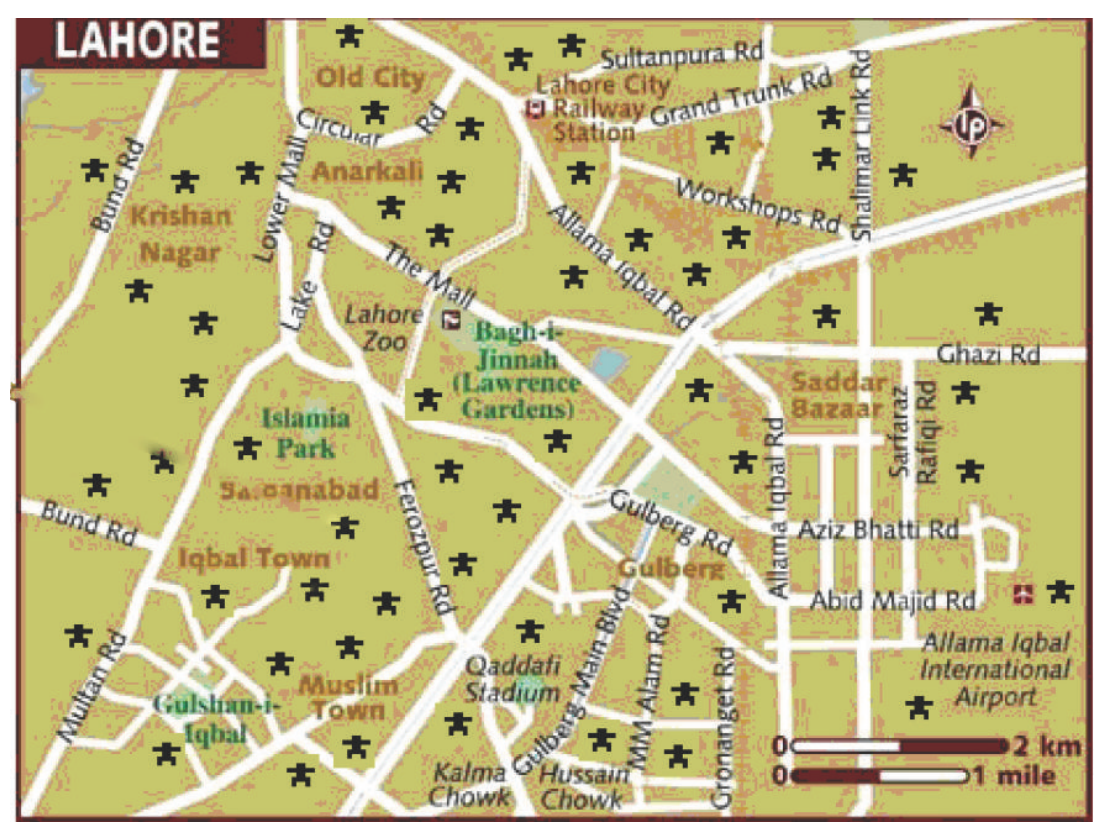

(a) Lahore

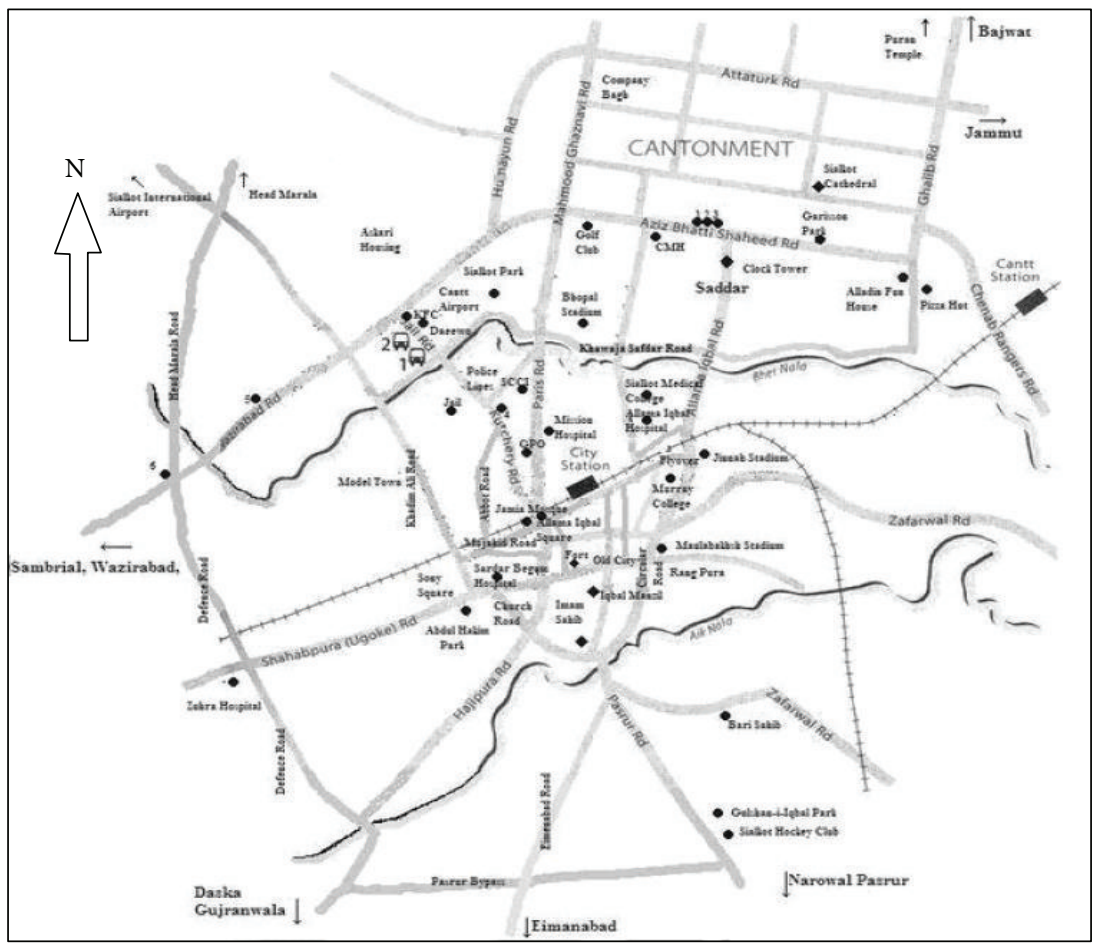

(b) Sialkot

FIGURE 1: Sampling location $(*)$ of drinking water samples from Lahore and Sialkot.

alkalinity values were observed for samples collected from Sialkot. The chloride levels of most of the localities of Lahore and Sialkot were found to be more enhanced than the permissible levels of $200 \mathrm{mg} / \mathrm{L}$ set by Pak-EPA and WHO. This is perhaps due to the reason that water is disinfected abundantly by the process of chlorination.
The nitrate and sulphate levels of the water samples are also quite important parameters for determining the quality of water. Both of these parameters were observed to be well below the limits set by WHO and PAK-EPA for samples collected from Lahore and Sialkot. Levels of fluoride as high as $6.0 \mathrm{mg} / \mathrm{L}$ were observed in groundwater samples from 


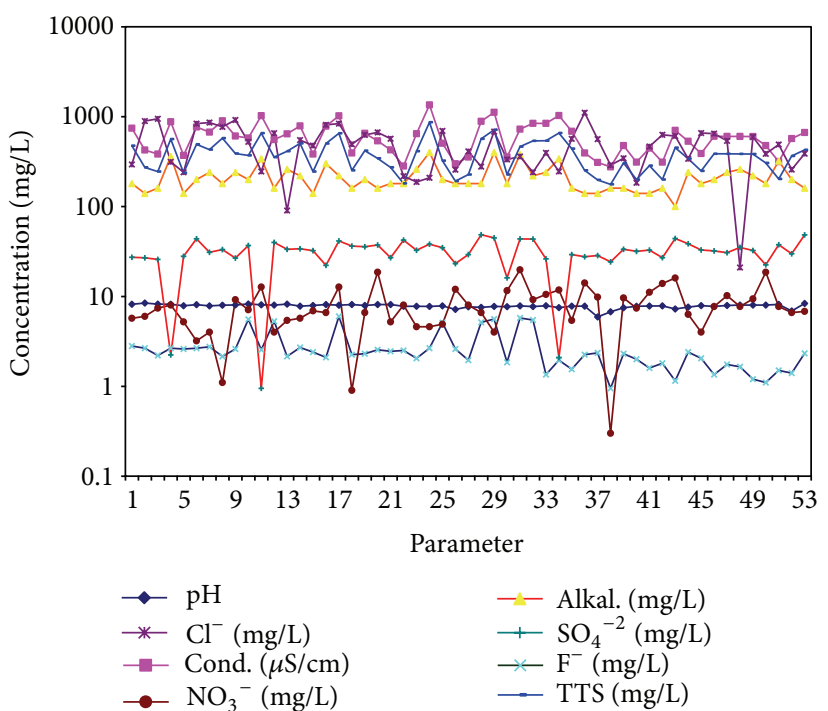

(a) Lahore

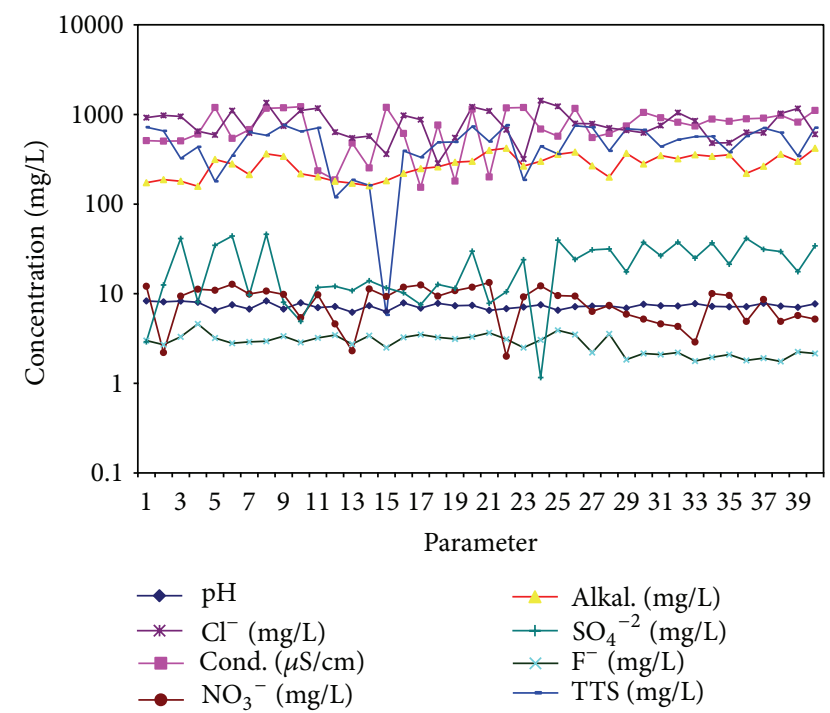

(b) Sialkot

FIGURE 2: Distribution of different parameters in drinking water samples from Lahore and Sialkot.

TABLE 1: Basic statistics for the physicochemical parameters of drinking water samples from Lahore and Sialkot.

\begin{tabular}{|c|c|c|c|c|c|c|c|c|}
\hline & $\mathrm{pH}$ & Cond. & Alkalinity $(\mathrm{mg} / \mathrm{L})$ & $\mathrm{F}^{-}(\mathrm{mg} / \mathrm{L})$ & $\mathrm{Cl}^{-}(\mathrm{mg} / \mathrm{L})$ & $\mathrm{NO}_{3}{ }^{-}(\mathrm{mg} / \mathrm{L})$ & $\mathrm{SO}_{4}^{-2}(\mathrm{mg} / \mathrm{L})$ & TTS (mg/L) \\
\hline \multicolumn{9}{|l|}{ Lahore } \\
\hline Minimum & 5.92 & 276 & 100 & 0.95 & 20.99 & 0.3 & 0.95 & 176.6 \\
\hline Maximum & 8.42 & 1353 & 400 & 6 & 1105.3 & 19.8 & 48.52 & 865.9 \\
\hline Range & 2.5 & 1077 & 300 & 5.05 & 1084.3 & 19.5 & 47.57 & 689.3 \\
\hline Mean & 7.813 & 604.5 & 211.6 & 2.603 & 496.5 & 8.121 & 31.41 & 386.9 \\
\hline Median & 7.88 & 600 & 180 & 2.3 & 490.9 & 7.4 & 32.37 & 384 \\
\hline Mode & 7.92 & 383 & 180 & 2.65 & 240.8 & 4 & 33.37 & 245.1 \\
\hline S.D. & 0.419 & 242.8 & 71.83 & 1.319 & 246.8 & 4.284 & 10.1 & 155.4 \\
\hline S.E. & 0.058 & 33.35 & 9.868 & 0.181 & 34.22 & 0.588 & 1.388 & 21.34 \\
\hline Variance & 0.175 & 58930 & 5160 & 1.74 & 60894 & 18.34 & 102.1 & 24137 \\
\hline Kurtosis & 7.858 & 0.485 & 0.851 & 1.249 & -0.543 & 0.792 & 2.481 & 0.485 \\
\hline Skewness & -2.329 & 0.809 & 1.212 & 1.485 & 0.339 & 0.844 & -1.182 & 0.809 \\
\hline \multicolumn{9}{|l|}{ Sialkot } \\
\hline Minimum & 6.2 & 153.6 & 158 & 1.75 & 285.3 & 2 & 1.16 & 5.8 \\
\hline Maximum & 8.3 & 1217 & 420 & 4.6 & 1425 & 13.3 & 46 & 759.9 \\
\hline Mean & 7.304 & 754.5 & 279.1 & 2.819 & 804.4 & 8.222 & 21.73 & 494.6 \\
\hline Median & 7.27 & 751.5 & 280 & 2.925 & 748.4 & 9.4 & 19.44 & 510.2 \\
\hline Mode & 6.54 & - & 180 & 3.3 & - & 9.4 & - & - \\
\hline SD & 0.539 & 333.2 & 78.202 & 0.68 & 286.2 & 3.296 & 13.07 & 203.7 \\
\hline SE & 0.085 & 52.68 & 12.365 & 0.108 & 45.25 & 0.521 & 2.067 & 32.2 \\
\hline Variance & 0.291 & 110996 & 6116 & 0.462 & 81890 & 10.86 & 170.9 & 41481 \\
\hline Kurtosis & -0.458 & -0.973 & -1.188 & -0.395 & -0.668 & -1.082 & -1.296 & -0.585 \\
\hline Skewness & 0.024 & -0.23 & 0.053 & 0.153 & 0.293 & -0.386 & 0.266 & -0.557 \\
\hline
\end{tabular}

Lahore. Sialkot on the other hand witnessed the highest fluoride level of $4.6 \mathrm{mg} / \mathrm{L}$. Many of the localities of Lahore and Sialkot exhibited fluoride levels that are much enhanced than Pak-EPA or WHO (Figure 2).

3.2. Basic Statistics for Physicochemical Parameters of Groundwater Samples. The data corresponding to the basic statistics for the fluoride and other physico-chemical parameters of the groundwater samples from Lahore and Sialkot is presented in Table 1, in terms of minimum, maximum, mean, median, mode, S.D., and S.E. The symmetry parameters for the data, that is, skewness and kertosis, are also enlisted in the table. The $\mathrm{pH}$ of the samples from Lahore was recorded to be in the range of 5.9 to 8.4 with a mean value standing at 7.8. 


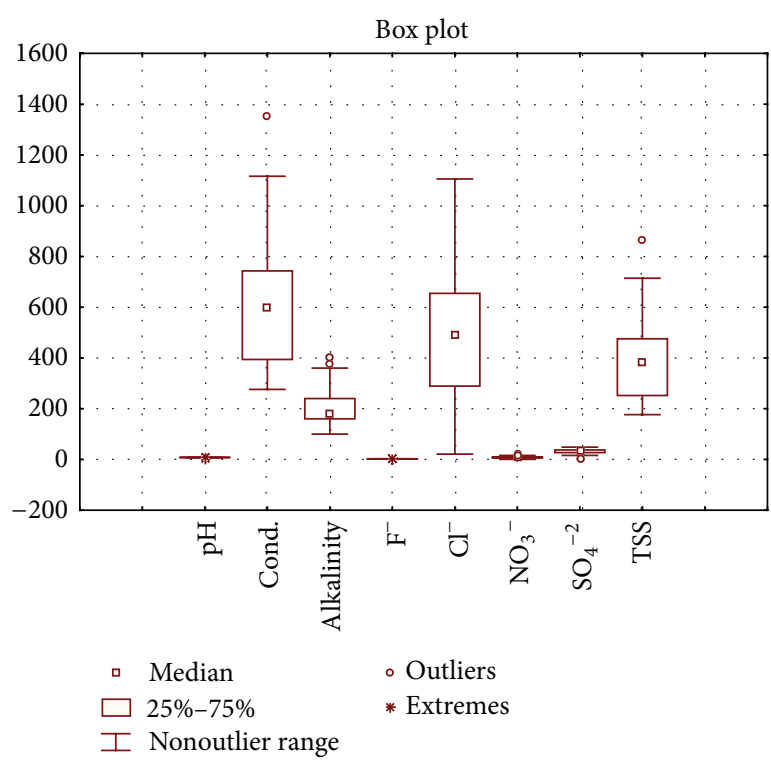

(a) Lahore

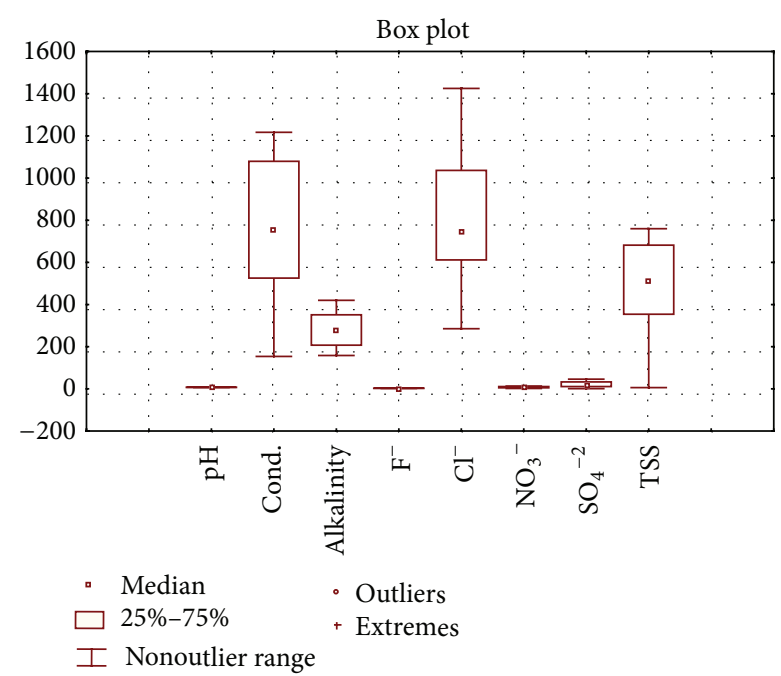

(b) Sialkot

FIGURE 3: Box plot for parameters from drinking water samples for Lahore and Sialkot.

Similarly, the $\mathrm{pH}$ values of the samples from Sialkot were found to range from 6.2 to 8.3 with the mean value standing at 7.3. The mean conductivity values of Lahore samples were found to be $604.5 \mu \mathrm{S} / \mathrm{cm}$, while that of Sialkot was found to be $754.5 \mu \mathrm{S} / \mathrm{cm}$, a much higher value than the previous case.

The maximum alkalinity values recorded for the samples from Lahore were $400 \mathrm{mg} / \mathrm{L}$. The mean values for alkalinity of Sialkot samples was reported to be $279.1 \mathrm{mg} / \mathrm{L}$ with standard deviation values of 78.20. The mean fluoride content of groundwater samples from Lahore was $2.603 \mathrm{mg} / \mathrm{L}$. The chloride content of these samples was quite high ranging from $20.99 \mathrm{mg} / \mathrm{L}$ to $1105 \mathrm{mg} / \mathrm{L}$ with its mean value of $494.4 \mathrm{mg} / \mathrm{L}$. The mean nitrate and sulphate levels of these samples were found to be $8.121 \mathrm{mg} / \mathrm{L}$ and $31.41 \mathrm{mg} / \mathrm{L}$, respectively. So the order of mean levels of various physico-chemical parameters was found to be $\mathrm{Cl}^{-}>$alkalinity $>\mathrm{SO}_{4}>\mathrm{NO}_{3}>\mathrm{F}^{-}$.

The fluoride content of the samples from Sialkot was found to range from 1.75 to $4.6 \mathrm{mg} / \mathrm{L}$ with a mean value of $2.819 \mathrm{mg} / \mathrm{L}$. The data showed that even minimum recorded values surpassed the limits set by WHO or Pak-EPA. Thus the whole studied Sialkot area was declared to be the floride area by the authors. The geology of the soil through which the water circulates along with the climate of Sialkot may contribute towards natural sources of $\mathrm{F}^{-}$in its groundwater [36]. Moreover, the use of phosphatic fertilizers for agriculture and sewage and industrial waste may also lead to high $\mathrm{F}^{-}$levels in groundwater [37]. Literature has evidenced that presence of large amounts of fluoride $(>1.5 \mathrm{mg} / \mathrm{L})$ in groundwater may cause dental and skeletal fluorosis $[38,39]$.

The chloride content of groundwater from Sialkot was recorded to possess the highest value, that is, $1425 \mathrm{mg} / \mathrm{L}$, among the measured parameters. Its mean values were found to stand at $804.7 \mathrm{mg} / \mathrm{L}$.
Nitrate in groundwater samples from Sialkot exhibited the levels in the range of 2 to $13.30 \mathrm{mg} / \mathrm{L}$ with mean value of $8.127 \mathrm{mg} / \mathrm{L}$ while the sulphate levels were found to be present with mean values of $21.73 \mathrm{mg} / \mathrm{L}$. In groundwater nitrate may result from agrochemicals, live stock facilities, and sewage disposal $[40,41]$. Excessive concentration of nitrate in the water is a big threat to the public health [42]. These have been shown to cause methemoglobinemia [43], while higher sulphate levels may become the cause of intestinal disorders [44]. The distribution of various parameters is also depicted in terms of box plots shown in Figure 3 and matrix plots (Figure 4).

\subsection{Correlation Coefficient Matrix for Physicochemical Param-} eters of Groundwater Samples. In order to trace the relationship among the various physico-chemical parameters, the correlation coefficient matrix was evaluated and presented in Table 2. The $r$ values were found to be significant at 0.229 for Lahore samples and at 0.265 for samples from Sialkot $(P>0.05)$. The strongest correlation was observed between conductance and alkalinity evidencing that in $66.1 \%$ of cases the conductance values went hand in hand with alkalinity values. Another significant correlation was observed between fluoride and sulphate with an $r$-value of 0.395 . Fluoride was also found to be significantly correlated with conductance with an $r$-value of 0.352 . The rest of the correlations observed were naïve. TSS was found to be significantly positively correlated with electrical conductivity, alkalinity, and fluoride content.

The correlation coefficient matrix for the groundwater samples from Sialkot evidenced strongest positive correlation between fluoride and nitrates with $r$ values of 0.520 . Alkalinity and conductance here were also found to be correlated significantly with $r$ values of 0.422 . Some of 

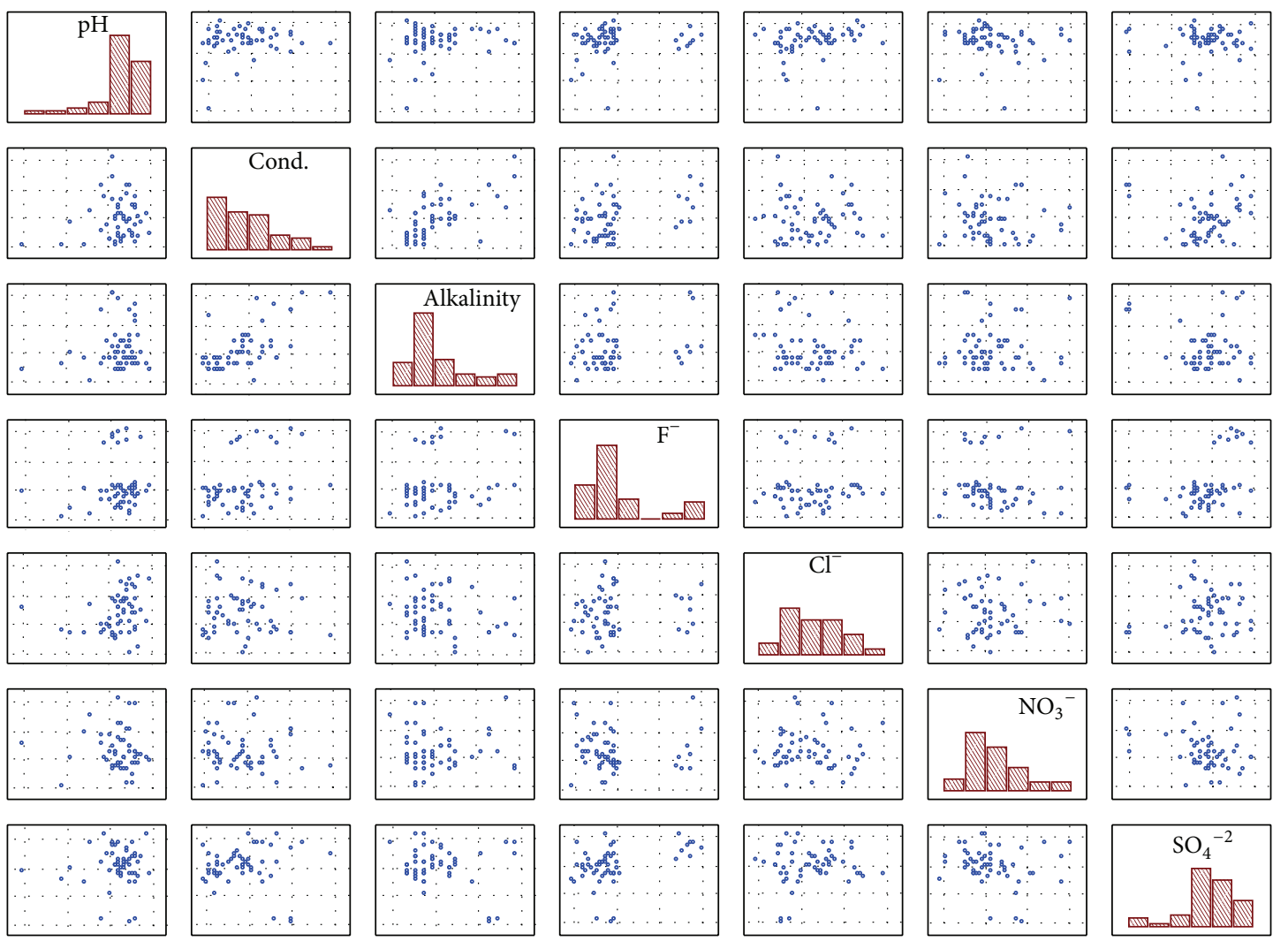

(a) Lahore

Matrix plot Sialkot
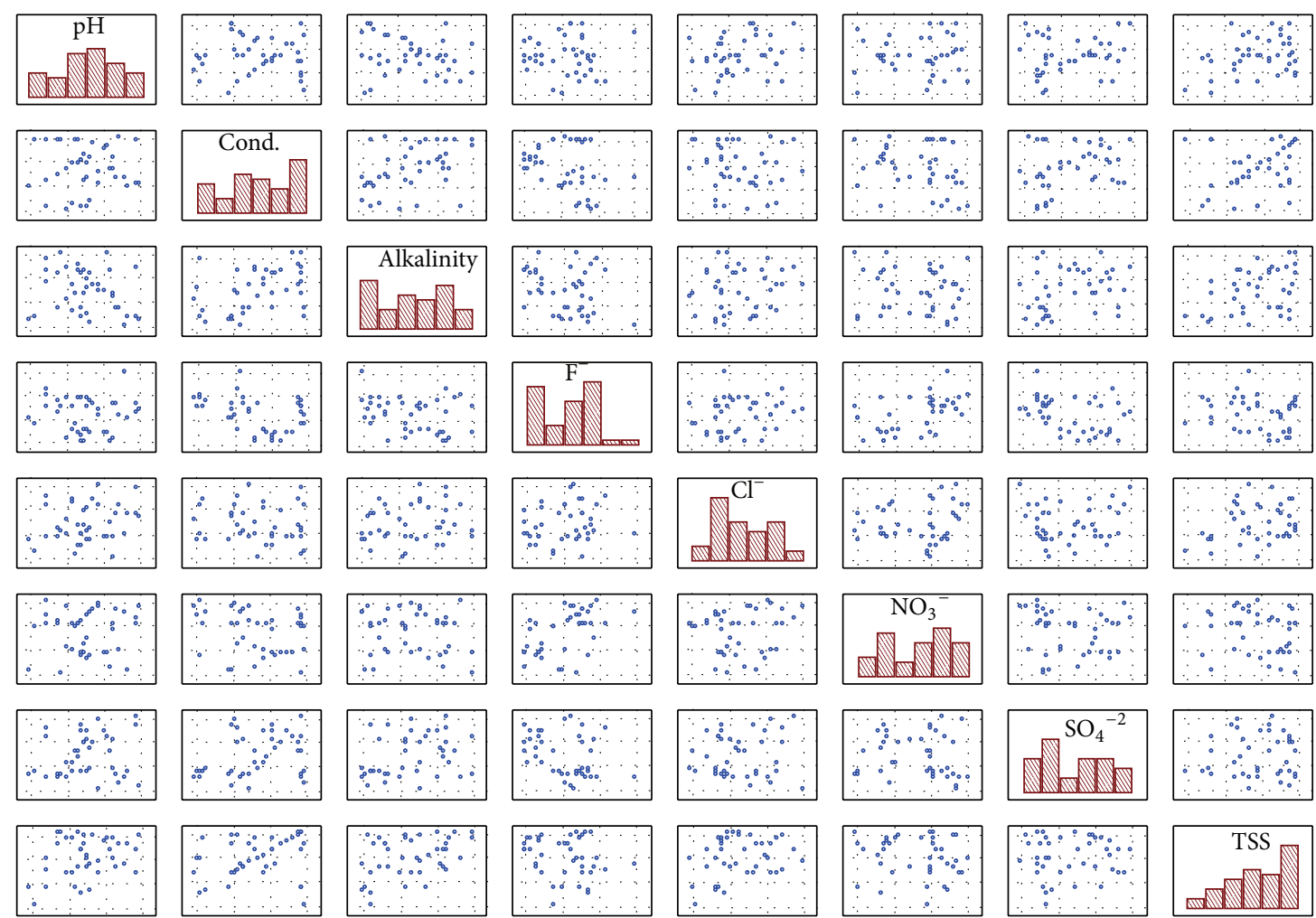

(b) Sialkot

FIgURE 4: Matrix plot for drinking water samples from Lahore and Sialkot. 
TABLE 2: Correlation coefficient matrix for the drinking water samples from Lahore and Sialkot.

\begin{tabular}{|c|c|c|c|c|c|c|c|c|}
\hline & $\mathrm{pH}$ & Cond. $(\mu \mathrm{S} / \mathrm{cm})$ & Alkal. (mg/L) & $\mathrm{F}^{-}(\mathrm{mg} / \mathrm{L})$ & $\mathrm{Cl}^{-}(\mathrm{mg} / \mathrm{L})$ & $\mathrm{NO}_{3}^{-}(\mathrm{mg} / \mathrm{L})$ & $\mathrm{SO}_{4}^{-2}(\mathrm{mg} / \mathrm{L})$ & TTS (mg/L) \\
\hline \multicolumn{9}{|l|}{ Lahore } \\
\hline $\mathrm{pH}$ & 1.000 & & & & & & & \\
\hline Cond. $(\mu \mathrm{S} / \mathrm{cm})$ & 0.172 & 1.000 & & & & & & \\
\hline Alkal. (mg/L) & 0.163 & 0.661 & 1.000 & & & & & \\
\hline $\mathrm{F}^{-}(\mathrm{mg} / \mathrm{L})$ & 0.138 & 0.352 & 0.243 & 1.000 & & & & \\
\hline $\mathrm{Cl}^{-}(\mathrm{mg} / \mathrm{L})$ & 0.218 & -0.048 & -0.218 & 0.116 & 1.000 & & & \\
\hline $\mathrm{NO}_{3}{ }^{-}(\mathrm{mg} / \mathrm{L})$ & -0.054 & -0.032 & 0.027 & -0.005 & -0.004 & 1.000 & & \\
\hline $\mathrm{SO}_{4}^{-2}(\mathrm{mg} / \mathrm{L})$ & 0.039 & 0.014 & -0.192 & 0.395 & 0.107 & -0.147 & 1.000 & \\
\hline TTS (mg/L) & 0.172 & 0.999 & 0.661 & 0.352 & -0.048 & -0.032 & 0.014 & 1.000 \\
\hline \multicolumn{9}{|l|}{ Sialkot } \\
\hline $\mathrm{pH}$ & 1.000 & & & & & & & \\
\hline Cond. $(\mu \mathrm{S} / \mathrm{cm})$ & 0.003 & 1.000 & & & & & & \\
\hline Alkal. (mg/L) & -0.196 & 0.422 & 1.000 & & & & & \\
\hline $\mathrm{F}^{-}(\mathrm{mg} / \mathrm{L})$ & -0.018 & -0.346 & -0.291 & 1.000 & & & & \\
\hline $\mathrm{Cl}^{-}(\mathrm{mg} / \mathrm{L})$ & 0.238 & -0.123 & 0.152 & 0.181 & 1.000 & & & \\
\hline $\mathrm{NO}_{3}{ }^{-}(\mathrm{mg} / \mathrm{L})$ & 0.043 & -0.215 & -0.098 & 0.520 & 0.159 & 1.000 & & \\
\hline $\mathrm{SO}_{4}{ }^{-2}(\mathrm{mg} / \mathrm{L})$ & 0.144 & 0.311 & 0.302 & -0.355 & 0.071 & -0.118 & 1.000 & \\
\hline TTS (mg/L) & 0.310 & 0.250 & 0.392 & -0.214 & 0.255 & -0.165 & 0.046 & 1.000 \\
\hline
\end{tabular}

Lahore $r$ values are significant at 0.229 at $P>0.05$.

Sialkot $r$ values are significant at 0.265 at $P>0.05$.

TABLE 3: Varimax normalized factor loading for various parameters of drinking water samples from Lahore and Sialkot.

\begin{tabular}{|c|c|c|c|c|c|}
\hline & \multicolumn{3}{|c|}{ Lahore } & \multicolumn{2}{|c|}{ Sialkot } \\
\hline & Factor 1 & Factor 2 & Factor 3 & Factor 1 & Factor 2 \\
\hline $\mathrm{pH}$ & 0.218 & -0.071 & 0.744 & -0.016 & 0.630 \\
\hline Cond. & 0.946 & 0.106 & 0.062 & 0.701 & 0.015 \\
\hline Alkalinity & 0.846 & -0.153 & -0.075 & 0.639 & 0.240 \\
\hline $\mathrm{F}^{-}$ & 0.390 & 0.650 & 0.207 & -0.779 & 0.177 \\
\hline $\mathrm{Cl}^{-}$ & -0.186 & 0.094 & 0.800 & -0.122 & 0.772 \\
\hline $\mathrm{NO}_{3}^{-}$ & 0.017 & -0.397 & 0.085 & -0.592 & 0.282 \\
\hline $\mathrm{SO}_{4}^{-2}$ & -0.102 & 0.876 & 0.082 & 0.547 & 0.158 \\
\hline TSS & 0.946 & 0.106 & 0.062 & 0.443 & 0.625 \\
\hline Expl. variance & 2.752 & 1.407 & 1.263 & 2.369 & 1.578 \\
\hline Prp. total & 0.344 & 0.176 & 0.158 & 0.296 & 0.197 \\
\hline Eigenvalue & 2.799 & 1.519 & 1.103 & 2.387 & 1.561 \\
\hline$\%$ Total variance & 34.99 & 18.99 & 13.79 & 29.83 & 19.51 \\
\hline Cumulative eigenvalue & 2.799 & 4.319 & 5.422 & 2.387 & 3.947 \\
\hline Cumulative \% & 34.99 & 53.99 & 67.78 & 29.83 & 49.34 \\
\hline
\end{tabular}

the physico-chemical parameters were also found to be significantly negatively correlated evidencing, that with the increase in concentration of one parameter, the concentration of another parameter simultaneously decreased; that is, $\mathrm{F}^{-}$ was significantly negatively correlated with sulphate with $r$ values of -0.355 .

3.4. Multivariate Statistical Analysis of Physicochemical Data. The sources of various physicochemical parameters in various water samples were traced in terms of multivariate analyses, that is, factor loading and cluster analysis. Varimax normalized factor loading for fifty-three samples from Lahore yielded four rotated factors (Table 3). Factor 1 with a \% total variance of 34.99 received major contribution from conductivity and alkalinity. A $21.51 \%$ total variance was associated with factor 2 . Among the major contributors of this factor fluoride and sulphate were included. $\mathrm{pH}$ and chloride were present as major contributors of factor 3 that enjoyed a cumulative $\%$ variance of 67.78 . Thus factor analysis attributed similar sources to $\mathrm{F}^{-}$and sulphates. The sources of these ions were traced in the soil formation as well as the history of industrial activity.

In groundwater different concentrations of fluoride may be present [45-48]. The percolation of phosphatic fertilizers 


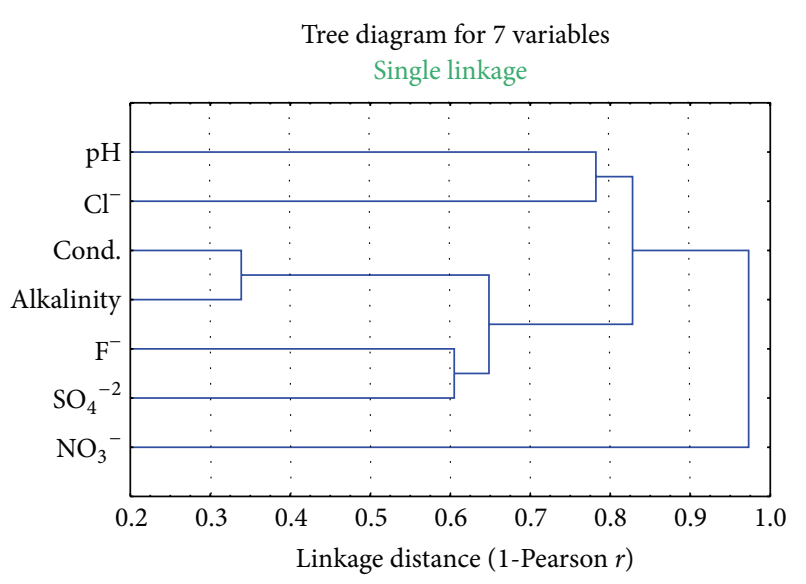

(a) Lahore

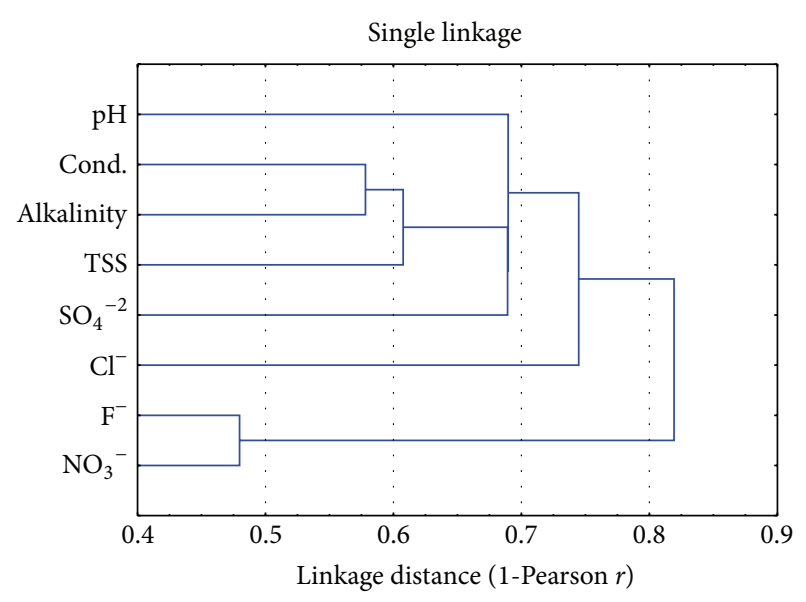

(b) Sialkot

FIGURE 5: Cluster analysis for parameters from drinking water samples from Lahore and Sialkot.

from agricultural runoff from nearby lands and discharge of domestic waste or the waste from surrounding industries increase the fluoride value [49]. Similarly, agricultural and industrial activities are sources of high sulphate in groundwater from Lahore. Since chloride and nitrates were present in different factors, their sources were different. The source of chloride was traced in chlorination process used for disinfection of drinking water sources. Chloride in natural water result from agricultural activities, industries and chloride rich rocks. High concentration of chloride is also due to invasion of domestic waste and disposal by human activities [49]. In drinking water high chloride contents may lead to laxative effects [50]. The groundwater contamination by nitrates results from the leaching of nitrate present on the surface of percolating soil [51].

In case of Sialkot, two rotated factors were obtained with a cumulative percentage of 49.34 and a cumulative eigenvalue of 3.947. Factor 1 accounting for an eigenvalue of 2.386 received major contribution from $\mathrm{F}^{-}$in addition to conductance. Factor 2 received major contribution from chloride and TSS with eigenvalue of 1.561. Nitrate was also the major contributor of factor 2. High nitrate content is an indicator of organic pollution. It results from the added nitrogenous fertilizers, decay of dead plants and animals and animal feces, and so forth. They all oxidize to nitrate by natural process, and hence nitrogen is present in the form of nitrates. The increase in one or all the above factors may be responsible for the increase of the nitrate content [52]. Low nitrate contents are due to lesser use of nitrogenous fertilizers and less disposal of waste around the studied area [53].

The cluster analysis of the data for the physico-chemical parameters of groundwater samples is presented in Figure 5. Single linkage method was used for the extraction of clusters that were depicted as a function of linkage distance. For samples from Lahore, the most significant primary cluster was formed by conductance and alkalinity within a linkage distance of 0.4 . Another primary cluster was formed between $\mathrm{F}^{-}$and sulphate within a linkage distance of 0.6 , thereby supporting the data of factor analysis where both parameters
TABLE 4: Comparison of mean levels with WHO standards.

\begin{tabular}{lcccc}
\hline Parameter & $\begin{array}{c}\text { Mean } \\
\text { (Lahore) }\end{array}$ & $\begin{array}{c}\text { Mean } \\
(\text { Peshawar })\end{array}$ & PAK-EPA & WHO \\
\hline $\mathrm{pH}$ & 7.8 & 7.3 & $7.0-8.5$ & $7.0-8.5$ \\
Conductivity & 604.5 & 754.5 & 600 & 600 \\
Alkalinity & 211.6 & 279.1 & 500 & 500 \\
$\mathrm{~F}^{-}(\mathrm{mg} / \mathrm{L})$ & 2.603 & 2.819 & 1.5 & 1.5 \\
$\mathrm{Cl}^{-}(\mathrm{mg} / \mathrm{L})$ & 496.5 & 804.4 & 200 & 250 \\
$\mathrm{NO}_{3}^{-}(\mathrm{mg} / \mathrm{L})$ & 8.121 & 8.222 & 45 & 50 \\
$\mathrm{SO}_{4}^{-2}(\mathrm{mg} / \mathrm{L})$ & 31.41 & 21.73 & 200 & 500 \\
\hline
\end{tabular}

were major contributors of a single factor. These two primary clusters were linked together to form a secondary cluster within linkage distance of 0.7 . Third primary cluster was constituted between $\mathrm{pH}$ and chloride, but the linkage distance for the formation of this cluster was 0.9 that was quite nonsignificant. Nitrate here exhibited an isolated role.

In the case of groundwater samples collected from Sialkot the most significant cluster was formed between nitrate and fluoride within a linkage distance of 0.5 . This cluster was associated with a secondary cluster formed by all other parameters. Within this secondary cluster the closest linkage was observed between conductivity and alkalinity. The cluster tree depicted that fluoride in water samples was sharing the same origin as that of nitrate.

A comparison of mean physico-chemical parameters of the groundwater samples collected from two cities with the PAK-EPA and WHO standards is depicted in Table 4. The mean $\mathrm{pH}$ values observed for Lahore and Sialkot were 7.8 and 7.4, respectively, that were well within the limits of Pak-EPA and WHO. The conductivity values for samples from Lahore slightly surpassed the limits, while the EC values from Sialkot were much enhanced than permissible limits evidencing a high content of dissolved salts in the respective water samples. The mean alkalinity values of the two cities were well within the limits. The mean $\mathrm{F}^{-}$and chloride concentration 
in groundwater samples from Lahore were much lower than those from Sialkot, but the levels of both anions present in Lahore and Sialkot were much elevated than limits set by PakEPA or WHO. The nitrate and sulfate levels from both cities were well within the limits.

\section{Conclusion}

The results of the present study demonstrated that some of the areas exhibited slightly high $\mathrm{pH}, \mathrm{EC}$, and TSS values, while a high contamination of the groundwater of both megacities was recorded with $\mathrm{F}^{-}$and $\mathrm{Cl}^{-}$. The high degree of contamination is the outcome of high industrial and agricultural activities in their vicinity. Thus all the above results confirmed that groundwater quality of the two cities is not up to the mark and is slowly degrading and in near future the groundwater resource will become completely polluted and unfit for portability and other purposes if appropriate strategies are not adopted. It is therefore high time to preserve and protect the valuable groundwater resources from devastation. For this purpose various management strategies may be adopted and most of all an awareness needs to be created among the public at large. Moreover, a continuous monitoring of groundwater resources and cautious fluoridation is needed to maintain the quality of drinking water.

\section{Conflict of Interests}

The author declares that there is no conflict of interest for the publication of this paper.

\section{References}

[1] V. K. Garg, A. Chaudhary, and D. S. Dahiya, "An appraisal of groundwater quality in some village of district Jind," Indian Journal of Environmental Protection, vol. 19, no. 4, pp. 267-272, 1999.

[2] K. Sukhdev, T. Deepika, G. S. Gill, N. Kishore, and S. Yadav, "Groundwater quality of Upper Ghaggar River Basin and its suitability for drinking and irrigation purposes," International Journal of Environmental Science, vol. 1, no. 3, pp. 295-305, 2010.

[3] O. Phiri, P. Mumba, B. H. Z. Moyo, and W. Kadewa, "Assessment of the impact of industrial effluents on water quality of receiving rivers in urban areas of Malawi," International Journal of Environmental Science and Technology, vol. 2, no. 3, pp. 237-244, 2005.

[4] M. Kumar, A. Ramanathan, and A. K. Keshari, "Understanding the extent of interactions between groundwater and surface water through major ion chemistry and multivariate statistical techniques," Hydrological Processes, vol. 23, no. 2, pp. 297-310, 2009.

[5] N. C. Mondal, V. K. Saxena, and V. S. Singh, "Impact of pollution due to tanneries on groundwater regime," Current Science, vol. 88, no. 12, pp. 1988-1994, 2005.

[6] S. Kaur and P. Malik, "Impact of industrial development on groundwater and surface water quality in industry dominating sectors of Chandigarh, India," Journal of Environment and Ecology, vol. 3, no. 1, pp. 2157-6092, 2012.

[7] R. Shyamala, M. Shanthi, and P. Lalitha, "Physicochemical analysis of borewell water samples of telungupalayam area in
Coimbatore District, Tamilnadu, India," E-Journal of Chemistry, vol. 5, no. 4, pp. 924-929, 2008.

[8] A. Ikem, S. Odueyungbo, N. O. Egiebor, and K. Nyavor, "Chemical quality of bottled waters from three cities in Eastern Alabama," Science of the Total Environment, vol. 285, no. 1-3, pp. 165-175, 2002.

[9] WHO, Guidelines for Drinking-Water Quality, Health Criteria and other Supporting Information, Addendum to Volume 2, Geneva, Switzerland, 2nd edition, 1998.

[10] S. Siddiq, Annual Report 2003.04, Sustainable Development Policy Institute, 2004, www.sdpi.orgs.

[11] M. B. Arain, T. G. Kazi, M. K. Jamali et al., "Evaluation of physico-chemical parameters of Manchar Lake water and their comparison with other global published palues," Pakistan Journal of Analytical and Environmental Chemistry, vol. 9, no. 2, pp. 101-109, 2008.

[12] U. S. EPA, "Drinking water criteria document on fluoride," TR823-5, US Environmental Protection Agency, Office of Drinking Water, Washington, DC, USA, 1985.

[13] W. Slooff, H. C. Eerens, J. A. Janus et al., "Basisdocument fluoriden," Report No. 758474005, National Institute of Public Health and Environmental Protection, Bilthoven, The Netherlands, 1988.

[14] S. M. Levy, M. C. Kiritsy, and J. J. Warren, "Sources of fluoride intake in children," Journal of Public Health Dentistry, vol. 55, no. 1, pp. 39-52, 1995.

[15] A. Farooqi, H. Masuda, M. Kusakabe, M. Naseem, and N. Firdous, "Distribution of highly arsenic and fluoride contaminated groundwater from east Punjab, Pakistan, and the controlling role of anthropogenic pollutants in the natural hydrological cycle," Geochemical Journal, vol. 41, no. 4, pp. 213-234, 2007.

[16] N. Mameri, A. R. Yeddou, H. Lounici, D. Belhocine, H. Grib, and B. Bariou, "Defluoridation of septentrional Sahara water of north Africa by electrocoagulation process using bipolar aluminium electrodes," Water Research, vol. 32, no. 5, pp. 1604$1612,1998$.

[17] A. A. Yam, M. Diouf/Ndiaye, M. Badiane, and G. Sawadogo, "Determination of the optimal fluoride dose in Senegal drinking water," Techniques, Sciences, Methodes, vol. 90, pp. 488-490, 1995.

[18] O. M. Sæther, C. Reimann, B. O. Hilmo, and E. Taushani, "Chemical composition of hard- and softrock groundwaters from central Norway with special consideration of fluoride and Norwegian drinking water limits," Environmental Geology, vol. 26, no. 3, pp. 147-156, 1995.

[19] J. P. Padmasiri, W. S. C. A. Fonseka, and T. Liyanapatabendi, "Low cost fluoride removal by an upward flow household filter," Water Supply, vol. 13, no. 3-4, pp. 59-64, 1995.

[20] A. K. Susheela, "Epidemiological studies of health risks from drinking water naturally contaminated with fluoride," in Proceedings of the Rome Symposium on Assessing and Managing Health Risks from Drinking Water Contamination: Approaches and Applications, E. G. Reichard and G. A. Zapponi, Eds., vol. 233 of IAHS, pp. 123-134, IAHS Press, Oxfordshire, UK, 1995.

[21] Z. Amor, B. Bariou, N. Mameri, M. Taky, S. Nicolas, and A. Elmidaoui, "Fluoride removal from brackish water by electrodialysis," Desalination, vol. 133, no. 3, pp. 215-223, 2001.

[22] A. K. Susheela, A. Kumar, M. Bhatnagar, and R. Bahadur, "Prevalence of endemic fluorosis with gastrointestinal manifestations in people living in some North-Indian villages," Fluoride - Quarterly Reports, vol. 26, no. 2, pp. 97-104, 1993. 
[23] R. Ahmed, Viqar-un-Nisa, M. Hussain, R. Tanwir, and S. A. Qureshi, Monitoring of Fluoride and Iodide Levels in Drinking Water Using Ion Selective Electrodes, Nuclear Chemistry Division, PINSTECH, Islamabad, Pakistan, 2005.

[24] L. S. Clesceri, A. E. Greenberg, and A. D. Eaton, Standard Methods for the Examination of Water and Wastewater, American Public Health Association, American Water Works Association, Water Environment Federation, Washington, DC, USA, 20th edition, 1998.

[25] Y. kara, I. Kara, and D. Basara, "Investigation of some physical and chemical parameters of water in the Lake Isykli in Denizli, Turkey," International Journal of Agriculture and Biology, vol. 1560-8530, pp. 275-277, 2004.

[26] F. O. Abulude, G. O. Obidiran, and S. Orungbemi, "Determination of physico-chemical parameter and trace metal contents of drinking water samples in akure Nigeria," Electronic Journal of Environmental, Agricultural and Food Chemistry, vol. 6, no. 8, pp. 2297-2303, 2007.

[27] D. P. Guptaa, Sunitaa, and J. P. Saharan, "Physiochemical analysis of ground water of selected area of Kaithal City (Haryana) India," Researcher, vol. 1, no. 2, pp. 1-5, 2009.

[28] American Public Health Association (APHA), American Water Works Association, and Water Pollution Control Federation, Standard Method for Examination of Water and Wastewater, APHA, AWWA and WPCF, New York, NY, USA, 2000.

[29] T. A. Bolaji and C. A. Tse, "Spatial variation in groundwater geochemistry and water quality index in Port Harcourt," Scientia Africana, vol. 8, no. 1, pp. 134-155, 2009.

[30] M. Radojevic and V. N. Bashkin, Practical Environmental Analysis, Royal Society of Chemistry Cambridge, Cambridge, UK, 1999

[31] P. Patnaik, Handbook of Environmental Analysis: Chemical Pollutants of Air, Water, Soil and Solid Wastes, CRC Lewis, 1997.

[32] A. Bartosova, A. Michalikova, M. Sirotiak, and M. Soldan, "Comparison of two spectrophotometric techniques for nutrients analyses in water samples," Research Papers, vol. 20, no. 32, pp. 8-19, 2012.

[33] M. S. Suresha, S. Mansour, A. Galil, M. D. Gowtham, and M. G. Nagendrappa, "Spectrophotometric determination of fluoride in drinking and wastewater," Journal of Saudi Chemical Society, vol. 10, no. 2, pp. 219-224, 2006.

[34] N. Kumaraswamy, "Physico-chemical analysis of ground water in pravara area, Dist. Ahmednagar, Maharashtra," Pollution Research, vol. 10, article 13, 1991.

[35] C. Srinivas, R. S. Piska, C. Venkateshwar, M. S. S. Rao, and R. R. Reddy, "Studies on ground water quality of hyderabad," Pollution Research, vol. 19, no. 2, pp. 285-289, 2000.

[36] W. Oelschlager, "Fluoride uptake in soil and its depletion," Fluoride, vol. 4, no. 2, pp. 80-84, 1971.

[37] A. B. Bhosle, R. K. Narkhede, B. Rao, and P. M. Patil, "Studies on the fluoride content of Godavari river water at Nanded," Ecology, Environment and Conservation, vol. 7, no. 3, pp. 341-344, 2001.

[38] G. Viswanathan, S. Gopalakrishnan, and S. Siva Ilango, "Assessment of water contribution on total fluoride intake of various age groups of people in fluoride endemic and non-endemic areas of Dindigul District, Tamil Nadu, South India," Water Research, vol. 44, no. 20, pp. 6186-6200, 2010.

[39] National Research Council, Health Effects of Ingested Fluoride, National Academic Press, Washington, DC, USA, 1993.

[40] R. F. Spalding and M. E. Exner, "Occurrence of nitrate in groundwater: a review," Journal of Environmental Quality, vol. 22, no. 3, pp. 392-402, 1993.
[41] G. D. Agrawal, S. K. Lunkad, and T. Malkhed, "Diffuse agricultural nitrate pollution of groundwaters in India," Water Science and Technology, vol. 39, no. 3, pp. 67-75, 1999.

[42] S. Ghosh, Environmental Chemistry, Dominant Publishers and Distributors, New Delhi, India, 2003.

[43] S. C. Santro, Environmental Science, New Central Book Agency Pvt, Kolkata, India, 2008.

[44] A. Durrani, "Physico-chemical parameters of ground-water," African Journal of Basic \& Applied Sciences, vol. 4, no. 2, pp. 2829, 2012.

[45] G. Karthikeyan, A. Shunmuga Sundarraj, and K. P. Elango, "Mapping of fluoride endemic areas and correlation studies of fluoride with other quality parameters of drinking water of Veppanapalli block of Dharmapuri district in Tamil Nadu," Indian Journal of Environmental Health, vol. 45, no. 4, pp. 281284, 2003.

[46] R. Gopal and P. K. Ghosh, "Fluoride in drinking water: its effects and removal," Defence Science Journal, vol. 35, no. 1, pp. 71-88, 1985.

[47] J. P. Yadav and S. Lata, "Fluoride levels in drinking water sources in rural areas of Block Jhajjar, District Jhajjar, Haryana," Journal of Indian Water Works Association, vol. 36, no. 2, pp. 131-136, 2004

[48] C. Dinesh, "Fluoride and human health causes for concern," Indian Journal of Environmental Protection, vol. 19, no. 2, pp. 8189, 1999.

[49] B. Guruprasad, "Assessment of water quality in canals of Krishna delta area of Andhra Pradesh," Nature of Environment and Pollution Technology, vol. 4, no. 4, pp. 521-523, 2005.

[50] S. Dahiya and A. Kaur, "Assessment of physico-chemical characteristics of underground water in rural areas," Environmental Journal of Pollution, vol. 6, no. 4, pp. 281-288, 1999.

[51] M. Kumar and R. Kumar, "Assessment of physico-chemical properties of ground water in granite mining areas in Jhansi, U.P.", International Journal of Engineering Research and Technology, vol. 1, article 7, 2012.

[52] Rahman, "Groundwater quality of Oman," in Groundwater Qual, pp. 122-128, Chapman and Hall, London, UK, 2002.

[53] S. Narain and R. Chauhan, "Water quality status of river complex Yamuna at Panchnada (Distt.: Etawah, U.P., India), I: An integrated management approach," Pollution Research, vol. 19, no. 3, pp. 357-364, 2000. 

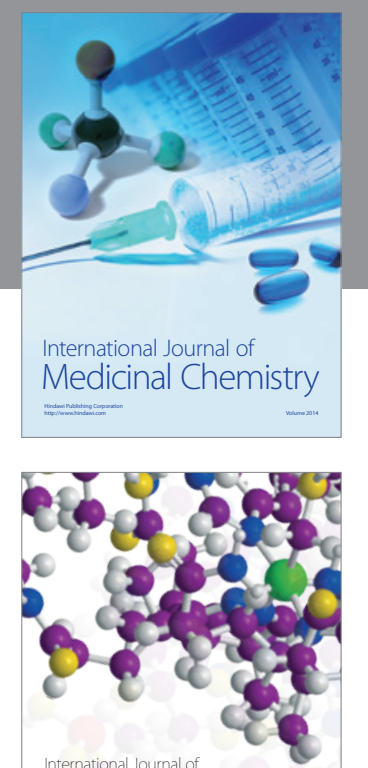

\section{Carbohydrate} Chemistry

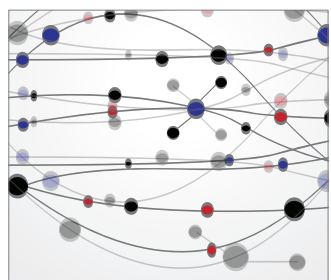

The Scientific World Journal
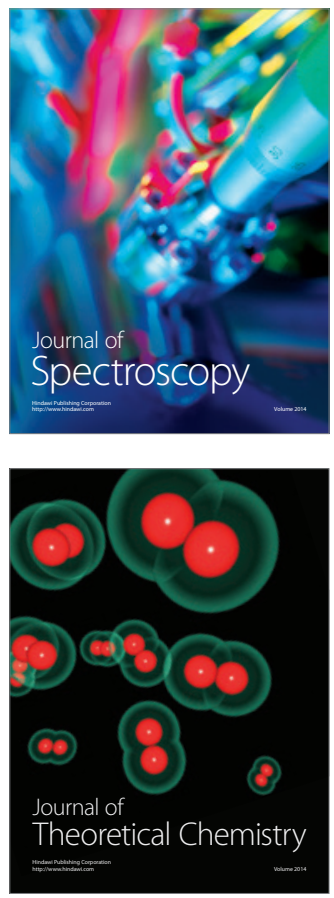
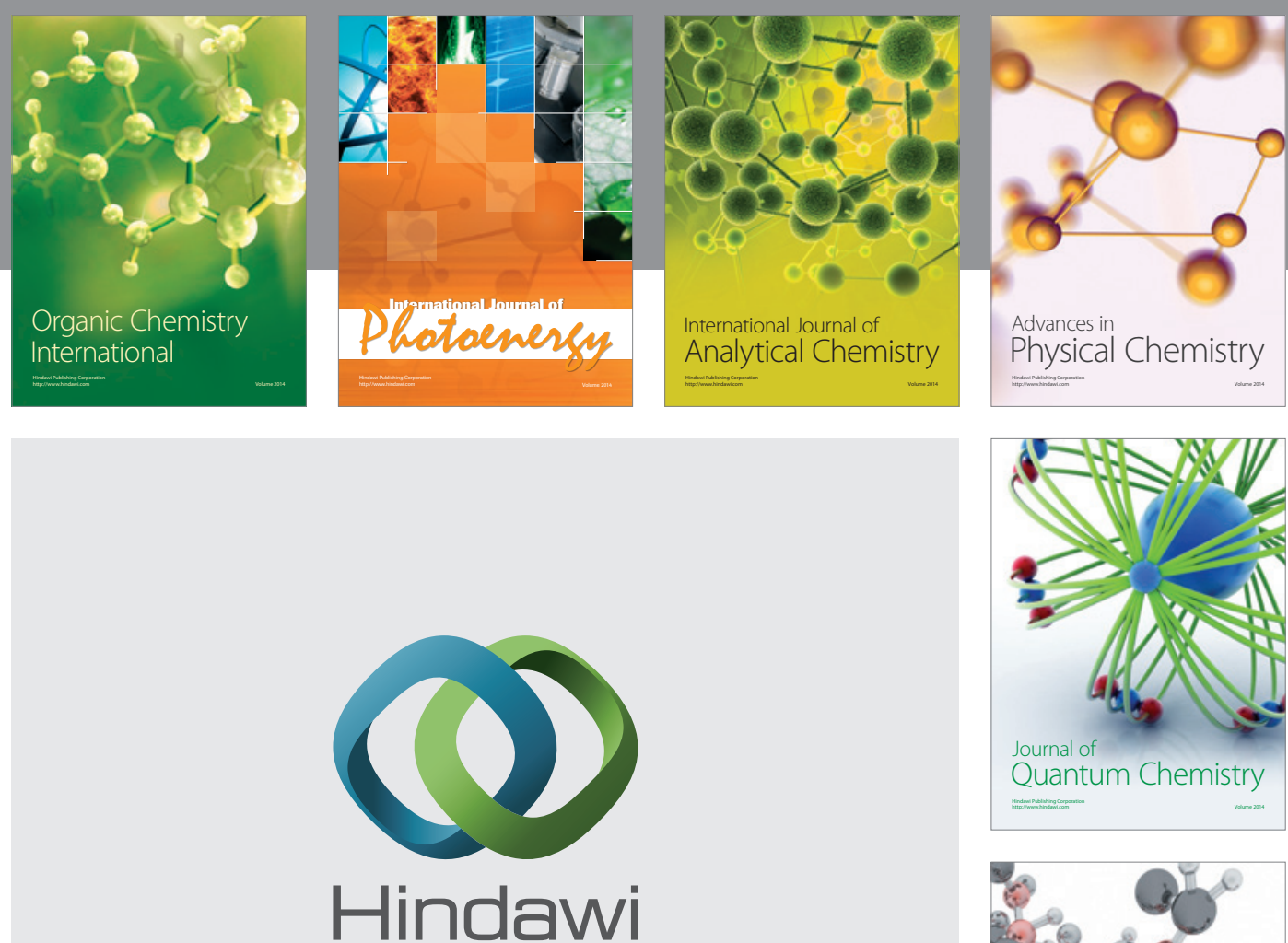

Submit your manuscripts at

http://www.hindawi.com

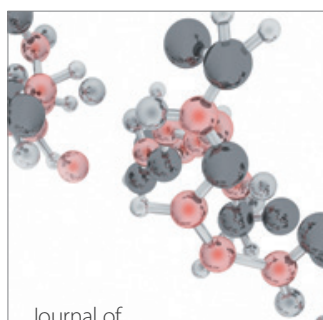

Analytical Methods

in Chemistry

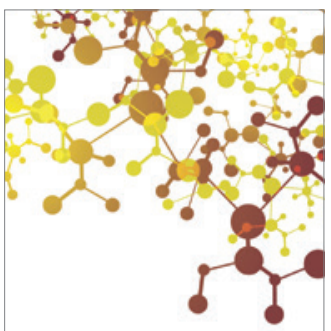

Journal of

Applied Chemistry

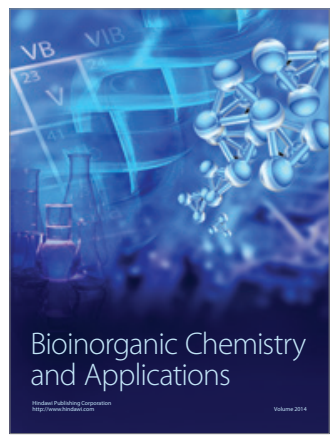

Inorganic Chemistry
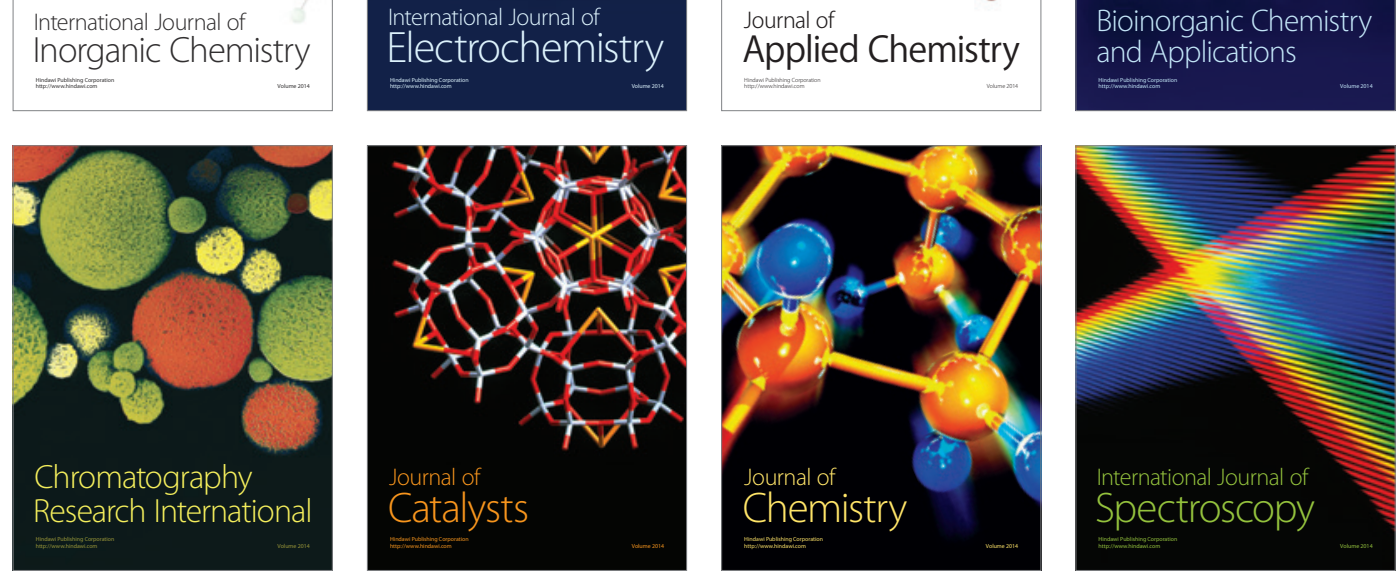